\title{
Illegal harvesting affects the success of fishing closure areas
}

\author{
GUSTAVO M. MARTINS ${ }^{1,2}$, STUART R. JENKINS ${ }^{3,4}$, STEPHEN J. HAWKINS ${ }^{3,4}$, ANA I. NETO ${ }^{1,5}$, \\ ANDRÉ R. MEDEIROS ${ }^{1}$ AND RICHARD C. THOMPSON ${ }^{2}$ \\ ${ }^{1}$ Secção Biologia Marinha, Departamento Biologia, Universidade dos Açores, 9501-801 Ponta Delgada, Açores, Portugal, ${ }^{2}$ Marine \\ Biology and Ecology Research Centre, Marine Institute, University of Plymouth, Plymouth PL4 8AA, UK, ${ }^{3}$ School of Ocean Sciences, \\ Bangor University, Menai Bridge, Anglesey LL59 5AB, UK, ${ }^{4}$ Marine Biological Association of the United Kingdom, Citadel Hill, \\ Plymouth PL1 2 PB, UK, ${ }^{5}$ Centro Interdisciplinar de Investigação Marinha e Ambiental (CIIMAR), Rua dos Bragas 289, 4050-123 \\ Porto, Portugal
}

\begin{abstract}
There is clear evidence that marine reserves can be used as effective tools to foster the recovery of disturbed ecosystems. In the Azores, intense exploitation of the patellid limpets Patella candei and P. aspera has led to a rapid decline in their populations and subsequent collapse of the fishery in 1985. In 1993, legislation was passed to protect limpets, including the establishment of limpet protected zones (LPZs) where harvesting was completely prohibited. Outside LPZs, a seasonal fishing closure prohibited the harvesting of limpets from October to May. Here we examine the effect of such measures 16 years after they were put into practice. In each of the 3 years examined, limpet density, biomass and size were generally similar both inside and outside the LPZs. In addition, there were clear signs of exploitation as most individual limpets inside the LPZ were smaller than the legal catch size suggesting that illegal harvesting was taking place. Observations confirmed that illegal harvesting of limpets was common both inside and outside LPZs. Lack of enforcement of regulations is therefore a likely reason for the failure of legislation to protect limpet populations and facilitate stock recovery.
\end{abstract}

Keywords: exploitation, marine protected areas (MPAs), limpet protected zones (LPZs), seasonal-fishing closures, Patella, limpet harvesting, poaching

Submitted 3 May 2010; accepted 26 May 2010

\section{INTRDDUCTION}

The number of over-exploited fish and shellfish stocks has increased markedly over the years (Jackson et al., 2001; Myers \& Worm, 2003) and this has led to a greater need to protect and conserve fished populations. Fishery management has traditionally been done in two forms: management of catch by restrictions of gear or catch limits, or management of effort, which can include limitation of the number of vessels or licences and the establishment of closed seasons (Roberts \& Polunin, 1991). These approaches, although mainly designed for single-species fisheries (Roberts \& Polunin, 1991), have been successful in many cases, leading to increased yields of exploited species (Ye, 1998; Govender et al., 2006; Fernández-Rueda \& García-Florez, 2007). The establishment of no-take marine reserves, areas closed to fishing or any extractive activity, has been suggested as a viable alternative to single-species fishery-management approaches (Roberts \& Polunin, 1991; Lubchenco et al., 2003) and there is mounting evidence that marine reserves have a diverse range of effects that are generally regarded as positive (Halpern \& Warner, 2002; Halpern, 2003; Micheli et al., 2004; Guidetti \& Sala, 2007; Claudet et al., 2008), making marine reserves an important tool in coastal management and conservation. For

Corresponding author:

G.M. Martins

Email: gmartins@uac.pt instance, since all fishing methods are size-selective, most targeting the larger individuals, fishing pressure will lead to a decrease in average size of target species. Cessation of fishing has been shown to increase average size of target species compared to fished areas (Branch, 1975; Bell, 1983; McClanahan \& Muthiga, 1988; Lasiak, 1993; Branch \& Moreno, 1994). Reduced mortality rates within reserves also result in increasing abundances of fished stocks (Bell, 1983; Alcala, 1988; Halpern, 2003; Micheli et al., 2004; Guidetti \& Sala, 2007). The combined effects of increased abundance and size can benefit adjacent fished areas via emigration of adults and juveniles across borders (spill-over effects) and via increased production and export of pelagic eggs and larvae (Gell \& Roberts, 2003; Kaunda-Arara \& Rose, 2004; Abesamis \& Russ, 2005). The effects of marine reserves appear stable and long-lasting (Shears \& Babcock, 2003) indicating that they can be used as a valuable strategy for the protection and management of fisheries.

The Azores archipelago is located in the North Atlantic (between $37^{\circ} \mathrm{N} 25^{\circ} \mathrm{W}$ and $40^{\circ} \mathrm{N} 31^{\circ} \mathrm{W}$ ) and comprises nine volcanic islands and several small islets. Human occupation dates back to the 15th Century and there is a local tradition of exploiting coastal biotic resources such as fish, lobsters, algae, limpets and barnacles for food (Morton et al., 1998). Limpets have been harvested probably since the islands were first colonized and were once the 6th most profitable fishery in the region, being an important source of income for many families (Ferraz et al., 2001). Due to their low mobility, intertidal limpets can be particularly vulnerable to harvesting. 
For instance, harvesting of the limpet Cymbula oculus in South Africa resulted in significant reductions in size, density, biomass, survivorship, reproductive output and in distorted sex-ratios (Branch \& Odendaal, 2003). In the Azores, uncontrolled harvesting of limpets during the early 1980 os resulted in dramatic decline in limpet populations and the fishery collapsed in 1985 (Martins et al., 1987; Santos et al., 1990; Hawkins et al., 2000) leading to dramatic changes in the community structure and functioning of Azorean coasts (Martins et al., 2008a). In 1993, legislation was passed to protect this resource including the establishment of limpet protected zones (LPZs), seasonal fishing closures and minimum legal catch sizes. LPZs comprise stretches of coast of a few kilometres where the collection of limpets is strictly prohibited throughout the year, although other extractive activities are permitted. Three to four LPZs were established in each of the nine islands of the archipelago. Management of LPZs is done via regular visits by the local authorities to the protected areas but no physical barriers exist.

In 2006, a monitoring programme was established in São Miguel, the most exploited of the nine islands (Martins et al., 2008a), to assess the effectiveness of LPZs and here we report on the first 3-years of data. The extent to which illegal harvesting could affect the success of LPZs was also examined.

\section{MATERIALS AND METHODS}

\section{Study sites}

The study was done in São Miguel Island, Azores. São Miguel is the most developed island of the archipelago with a human population of $\sim 130,000$ in 2007 (SREA-Secretaria Regional de Estatística dos Açores). The main economic activities are dairy and fisheries although tourism is a developing industry.
The study described and compared the population structure of limpets between two LPZs established in 1993, Caloura and Maia, and two locations outside LPZs, Lagoa and Fenais-da-Luz (Figure 1), during 3 replicate years (20062008). Inside LPZs, limpet harvesting is completely prohibited throughout the year. Outside the LPZs, there is a seasonal fishing closure between October and May that prohibits the harvesting of limpets. However, between June and September, limpet harvesting is allowed although there are minimum legal catch sizes of 30 and $55 \mathrm{~mm}$ shell length for Patella candei d'Orbigny, 1840 and P. aspera Röding, 1798, respectively. The two locations selected outside the LPZs (hereafter referred to as seasonal closed areas (SCAs)) were considered to be representative of the remainder of the coast.

The four locations examined each comprised a stretch of the coast of $500 \mathrm{~m}$ and supported similar assemblages of animals and plants. The dominant space occupiers were turfforming algae (e.g. articulated coralline algae, Gelidium spp. and Caulacanthus ustulatus) lower on the shore and the chthamalid barnacle Chathamalus stellatus upper on the shore. The four locations were all exposed to wave-action, had steep slope and were made of basaltic rock. There was no a priori reason to believe that LPZs and SCAs differ in any way other than the level of protection. However, since the two selected LPZs were located respectively on the southern or northern coasts, which may differ in exposure to swell due to the prevailing north-easterly winds (Instituto Hidrográfico, 2006), the two SCAs were respectively selected on the northern and southern coasts to match conditions in the two LPZs.

\section{Sampling design}

Data on limpet population structure from periods prior to the establishment of LPZs were not available. Hence, to examine
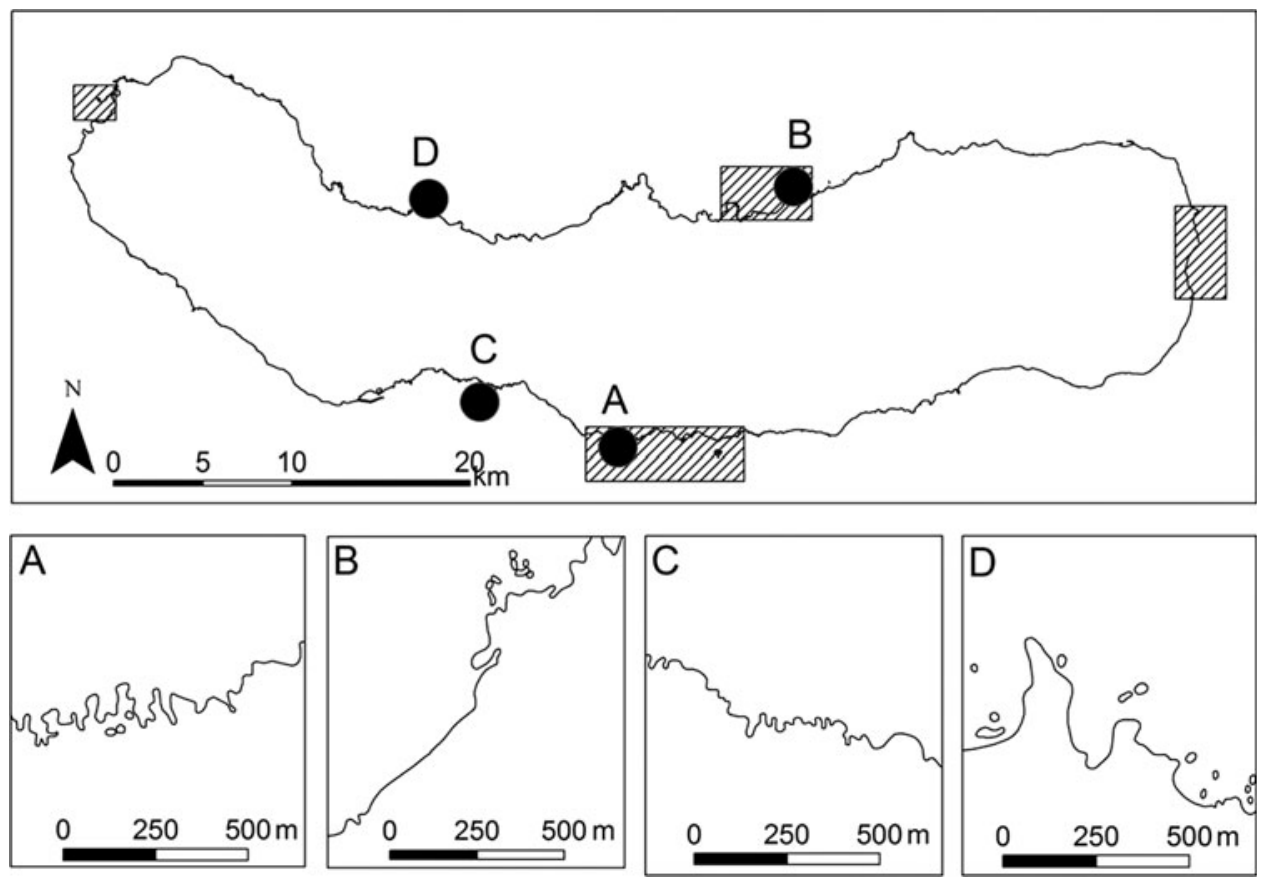

Fig. 1. Map of São Miguel Island showing the established limpet protected zones (shaded areas) and the sampled locations (filled circles): A, Caloura; B, Maia; C, Lagoa; D, Fenais. 

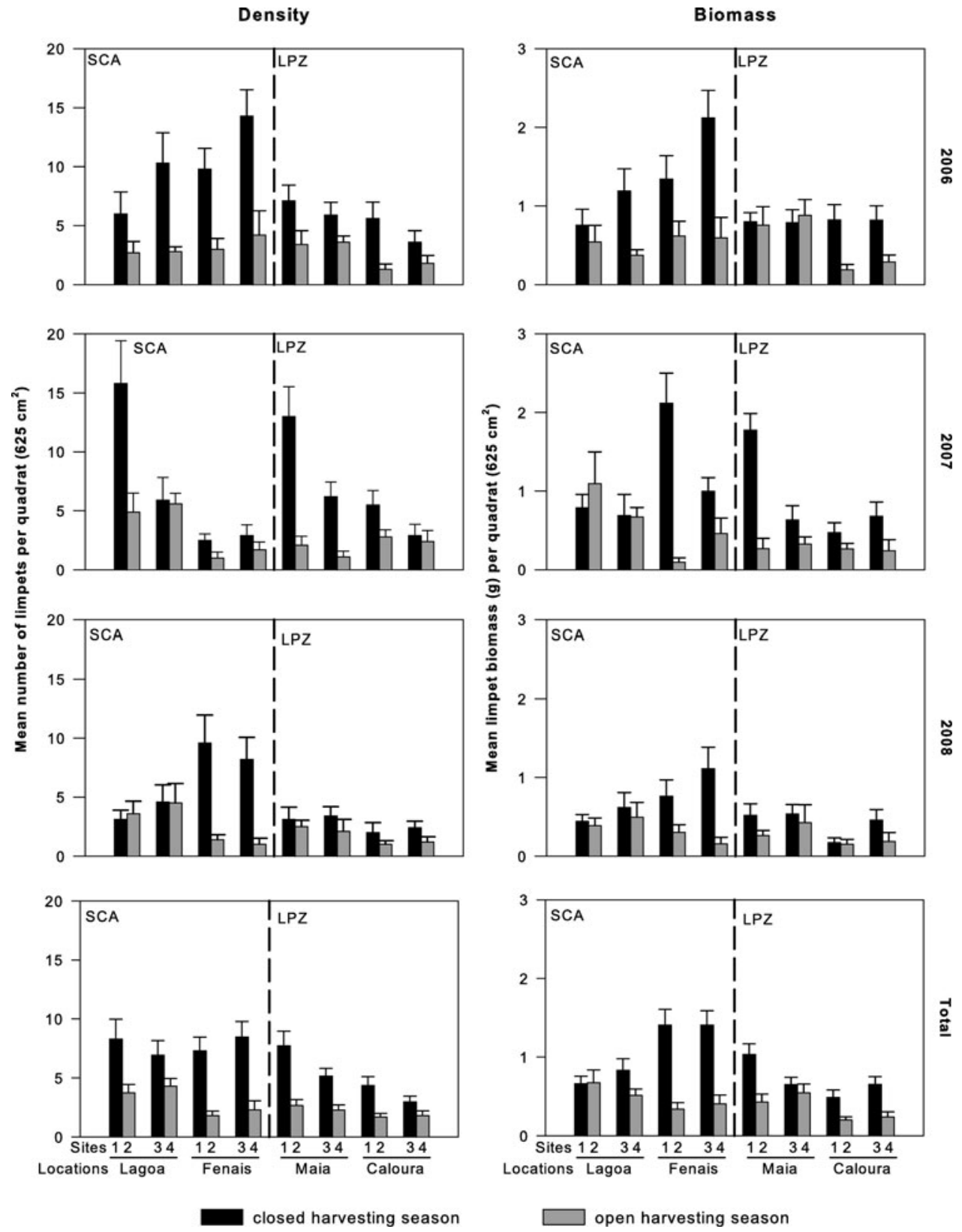

Fig. 2. Mean $( \pm 1 S E)$ density and biomass of Patella candei at the end of the open and closed harvesting seasons. Data are presented for each year separately and combined. SCA, seasonal closed area; LPZ, limpet protected zone. Numbers $1-4$ indicate the sites examined within each location at each of the harvesting seasons, respectively.

the effectiveness of LPZs in enhancing the stocks of limpets, the population structure of the exploited limpet Patella candei was compared between the four locations over a period of 3 years. Formal comparisons were made for $P$. candei, but not $P$. aspera, as the latter is rare in the intertidal throughout São Miguel (Martins et al., 2008a).

At each location, a total of four sites were haphazardly selected at least $30 \mathrm{~m}$ apart. Two interspersed sites were assigned to the open harvesting season, whereas the remaining two sites were assigned to the closed harvesting season (see below for further details). Within each site, all $P$. candei within ten $25 \times 25 \mathrm{~cm}$ quadrats were counted and their shell length measured to the nearest millimetre. No animals were dislodged during sampling. The vertical position of samples was defined by the major biological patterns on the shore. Sampling was done in the barnacle zone immediately above the upper vertical limit of the dense cover of turfforming algae that characterized the lower shore. This corresponded to the tidal level where the abundance of $P$. candei was greatest (Martins et al., 2008b). Analysis of data considered limpet density, size and biomass. The weight of each limpet was estimated indirectly using a previously calculated length-weight relationship (biomass $(\mathrm{g})=0.0001 \times$ shell length $(\mathrm{mm})^{2.79}, \mathrm{r}^{2}=0.96$; Martins et al., 2008a; Martins, 2009). The estimated biomass of all animals in each quadrat was summed and used in the analysis.

Illegal harvesting of limpets was known to occur in the Azores (Martins, personal observation). To estimate its intensity, the number of limpet harvesters was recorded during each field trip to the shore (these were not restricted to visits made for the purpose of the present study). Although these data were not collected in a structured way (with 
Table 1. Four-way mixed model ANOVA comparing the abundance and biomass of Patella candei at the end of the open and closed harvesting seasons in areas differing in the level of protection (limpet protected zone versus seasonally closed area). Data were pooled over the three years of the study.

\begin{tabular}{|c|c|c|c|c|c|c|}
\hline \multirow[t]{2}{*}{ Source } & \multirow[t]{2}{*}{ df } & \multicolumn{2}{|l|}{ Density } & \multicolumn{2}{|l|}{ Biomass } & \multirow[t]{2}{*}{ F ratio } \\
\hline & & MS & $\mathbf{F}$ & MS & $\mathbf{F}$ & \\
\hline Season $=\mathrm{Se}$ & 1 & 56.97 & 14.83 & 8.59 & 6.00 & $\mathrm{~S} \times \mathrm{L}(\mathrm{P})$ \\
\hline Protection $=\operatorname{Pr}$ & 1 & 5.94 & 1.18 & 1.68 & 1.79 & $\mathrm{~L}(\mathrm{P})$ \\
\hline Location $=\mathrm{Lo}(\mathrm{Pr})$ & 2 & 5.03 & $14.91^{* *}$ & 0.94 & $8.89^{* *}$ & Site $(\mathrm{S} \times \mathrm{L}(\mathrm{P}))$ \\
\hline Site $(\mathrm{Se} \times \operatorname{Lo}(\operatorname{Pr}))$ & 8 & 0.34 & 0.52 & 0.11 & 0.94 & Residual \\
\hline Se $\times \operatorname{Pr}$ & 1 & 0.71 & 0.18 & 0.25 & 0.17 & $\mathrm{~S} \times \mathrm{L}(\mathrm{P})$ \\
\hline Se $\times \operatorname{Lo}(\operatorname{Pr})$ & 2 & 3.84 & $11.38^{* *}$ & 1.43 & $13.59^{* *}$ & Site $(\mathrm{S} \times \mathrm{L}(\mathrm{P}))$ \\
\hline Residual & 464 & 0.65 & & 0.11 & & \\
\hline Transformation & & $\operatorname{Ln}(x+1)$ & & $\operatorname{Ln}(x+1)$ & & \\
\hline Cochran's & & $C=0.09$ & & $C=0.11$ & & \\
\hline
\end{tabular}

Student-Newman-Keuls test on the $\mathrm{S} \times \mathrm{L}(\mathrm{P})$ interaction

$\begin{array}{lll} & \text { Density } & \text { Biomass } \\ \text { SCA } & \text { Lagoa: closed }>\text { open } & \text { Lagoa: closed }=\text { open } \\ \text { SCA } & \text { Fenais: closed }>\text { open } & \text { Fenais: closed }>\text { open } \\ \text { LPZ } & \text { Maia: closed }>\text { open } & \text { Maia: closed }>\text { open } \\ \text { LPZ } & \text { Caloura: closed }>\text { open } & \text { Caloura: closed }>\text { open }\end{array}$

Here and afterwards: ${ }^{*}, P<0.05$; $^{* *}, P<0.01$; $^{* *}, P<0.001$.

respect to times of day, season, or number of replicates) they did provide an indication of the frequency of limpet harvesting throughout the study period. In the first 2 years of the study, analyses of limpet abundance revealed no significant differences between fished areas and LPZs (see Tables 2 \& 3), suggesting that illegal harvesting was nullifying the intended protection of limpets in LPZs. This motivated a more standardized estimation of the intensity of illegal harvesting, which was done during the third year of the study. This was accomplished by assessing the number of limpet harvesters per day on each of 10 randomly selected occasions in each of two seasons: closed and open. Each sampling event had a fixed duration of 2 hours (starting $\sim_{1}$ hour before low tide). Due to logistical constraints, data on harvesting were collected only at two of the four locations: Caloura (LPZ) and Lagoa (SCA), which are both on the south coast.
We recognize that this design is pseudo-replicated in that only one location per level of protection was sampled. However, given the logistical constraints, we opted to maximize sampling effort by increasing the number of visits made to two locations at the expense of a properly balanced design. The results must therefore be interpreted with caution, and in the light of other potential influences on the effectiveness of LPZs. The data on harvesting gathered in the first 2 years in an unstructured manner are hereafter referred to as 'non-standardized', and the data gathered in a formal manner in the third year as 'standardized'.

\section{Data analysis}

Data were analysed using analysis of variance (ANOVA). Prior to analysis, data were checked for heterogeneity of

Table 2 Four-way mixed model ANOVA comparing the abundance of Patella candei at the end of the open and closed harvesting seasons in areas differing in the level of protection (limpet protected zone versus seasonally closed area). Legend and $P$ values as in Table 1 .

\begin{tabular}{|c|c|c|c|c|c|c|c|}
\hline \multirow[t]{2}{*}{ Source } & \multirow[t]{2}{*}{ df } & \multicolumn{2}{|l|}{2006} & \multicolumn{2}{|l|}{2007} & \multicolumn{2}{|l|}{2008} \\
\hline & & MS & $\mathbf{F}$ & MS & $\mathbf{F}$ & MS & $\mathbf{F}$ \\
\hline $\mathrm{Se}$ & 1 & 35.47 & $34 \cdot 36^{*}$ & 24.17 & 6.05 & 11.81 & 1.96 \\
\hline $\operatorname{Pr}$ & 1 & 6.21 & 1.67 & 0.18 & 0.01 & 7.86 & 8.37 \\
\hline $\operatorname{Lo}(\operatorname{Pr})$ & 2 & 3.72 & 5.78 & 13.55 & $5.65^{*}$ & 0.94 & $6.50^{*}$ \\
\hline Site $(\mathrm{Se} \times \operatorname{Lo}(\operatorname{Pr}))$ & 8 & 0.64 & 0.87 & 2.40 & $3.74^{* * *}$ & 0.14 & 0.28 \\
\hline Se $\times \operatorname{Pr}$ & 1 & 3.20 & 3.10 & 1.17 & 0.29 & 2.62 & 0.44 \\
\hline $\mathrm{Se} \times \operatorname{Lo}(\operatorname{Pr})$ & 2 & 1.03 & 1.61 & 4.00 & 1.66 & 6.02 & $41.74^{* * *}$ \\
\hline Residual & 144 & 0.74 & & 0.64 & & 0.51 & \\
\hline Transformation & & sq-rt & & sq-rt & & sq-rt & \\
\hline Cochran's & & $C=0.17$ & & $C=0.16$ & & $C=0.15$ & \\
\hline
\end{tabular}

Student-Newman-Keuls test on the $\mathrm{S} \times \mathrm{L}(\mathrm{P})$ interaction 
Table 3. Four-way mixed model ANOVA comparing the biomass of Patella candei at the end of the open and closed harvesting seasons in areas differing in the level of protection (limpet protected zone versus seasonally closed area). Legend and $P$ values as in Table 1.

\begin{tabular}{|c|c|c|c|c|c|c|c|}
\hline \multirow[t]{2}{*}{ Source } & \multirow[t]{2}{*}{ df } & \multicolumn{2}{|l|}{2006} & \multicolumn{2}{|l|}{2007} & \multicolumn{2}{|l|}{2008} \\
\hline & & MS & $\mathbf{F}$ & MS & $\mathrm{F}$ & MS & $\mathbf{F}$ \\
\hline Se & 1 & 1.55 & $7 \cdot 30$ & 231.51 & 3.05 & 0.51 & 3.89 \\
\hline $\operatorname{Pr}$ & 1 & 0.29 & 0.87 & 24.46 & 2.48 & 0.23 & 3.19 \\
\hline $\operatorname{Lo}(\operatorname{Pr})$ & 2 & 0.33 & $6.27^{*}$ & 9.87 & 0.66 & 0.07 & 2.94 \\
\hline Site $(\mathrm{Se} \times \operatorname{Lo}(\operatorname{Pr}))$ & 8 & 0.05 & 0.97 & 15.02 & $2.62^{*}$ & 0.02 & 0.79 \\
\hline Se $\times \operatorname{Pr}$ & 1 & 0.28 & 1.32 & 0.78 & 0.01 & 0.06 & 0.48 \\
\hline $\mathrm{Se} \times \operatorname{Lo}(\operatorname{Pr})$ & 2 & 0.21 & 4.01 & 75.85 & $5.05^{*}$ & 0.13 & $5.39^{*}$ \\
\hline Residual & 144 & 0.05 & & 5.74 & & 0.03 & \\
\hline Transformation & & sq-rt & & ArcSin & & sq-rt & \\
\hline Cochran's & & $C=0.13$ & & $C=0.17$ & & $C=0.16$ & \\
\hline
\end{tabular}

Student-Newman-Keuls test on the $\mathrm{S} \times \mathrm{L}(\mathrm{P})$ interaction

$\begin{array}{lll} & 2007 & 2008 \\ \text { SCA } & \text { Lagoa: closed }=\text { open } & \text { Lagoa: closed = open } \\ \text { SCA } & \text { Fenais: closed }>\text { open } & \text { Fenais: closed }>\text { open } \\ \text { LPZ } & \text { Maia: closed }>\text { open } & \text { Maia: closed }=\text { open } \\ \text { LPZ } & \text { Caloura: closed }=\text { open } & \text { Caloura: closed }=\text { open }\end{array}$

closed harvesting season

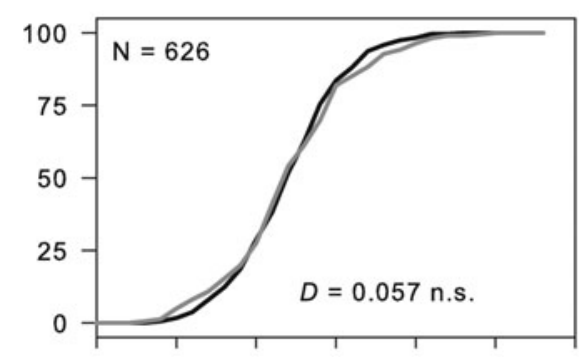

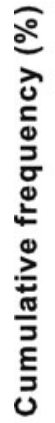
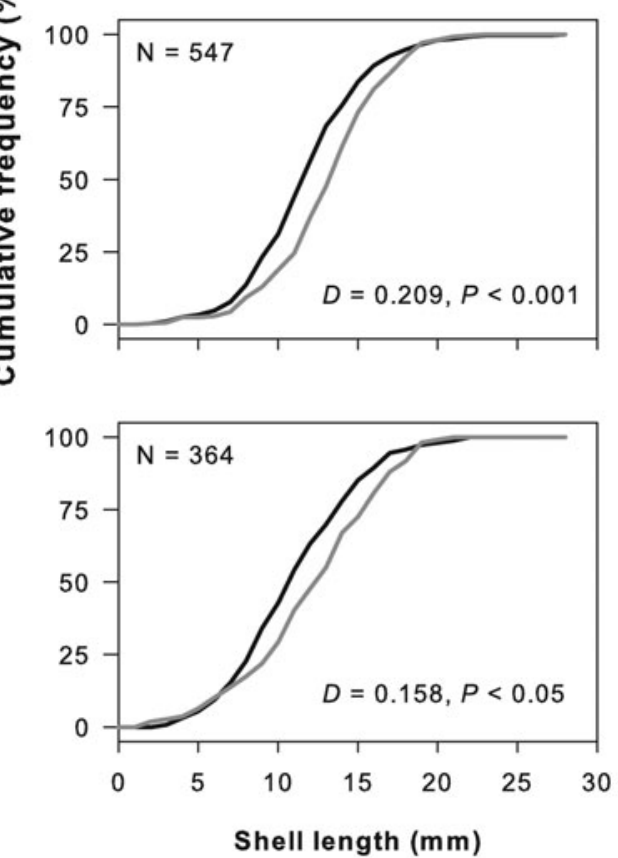

$\longrightarrow$ SCA open harvesting season
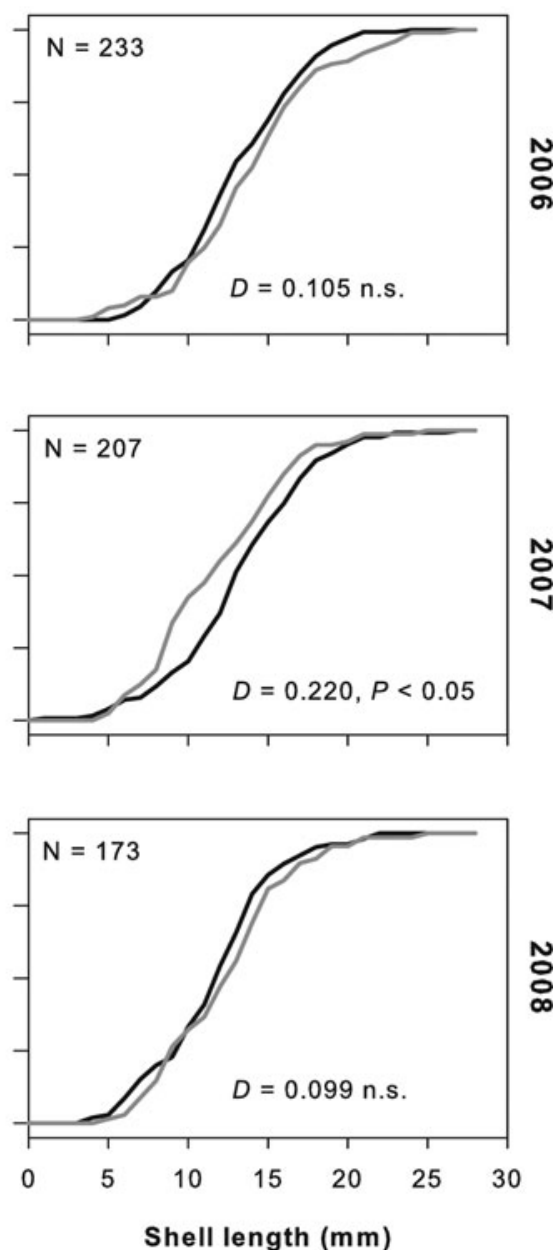

LPZ

Fig. 3. Cumulative frequency of population size structure of Patella candei. Data were pooled among locations. The result of the Kolmogorov-Smirnov test is shown. SCA, seasonally closed area; LPZ, limpet protected zone; n.s., not significant at $\alpha=0.05$. 


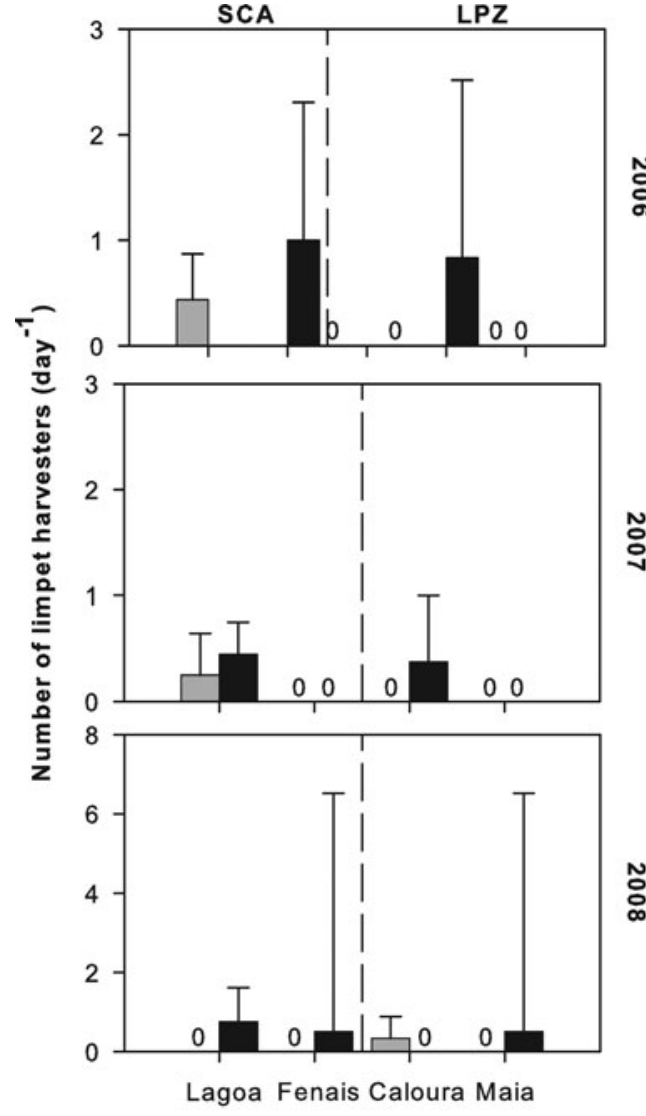

(A) 'unstandardized' comparison

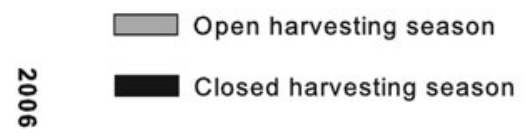

ํํํ

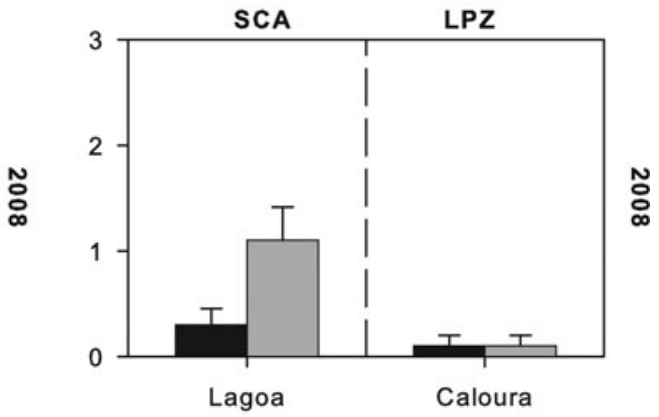

(B) 'standardized' comparison

Fig. 4. Mean (+CI) number of limpet harvesters recorded over the 3 years of the study estimated in an 'unstandardized' way (A) and mean (+SE) number of limpet harvesters recorded in 2008 in a 'standardized' way (see Materials and Methods for further description) (B). SCA, seasonally closed area; LPZ, limpet protected zone. Zeros ('o') indicate that no harvesters were seen during sampling. Note differences in y-axes scales and that only one location was used per level of protection (SCA versus LPZ) in the 'standardized' comparison.

variances using the Cochran's test and transformations were applied where appropriate (Underwood, 1997). To examine the cumulative effects of protection, data were first analysed by combining data corresponding to each site from each of the 3 years. Mean limpet density and biomass were analysed using a four-way mixed model ANOVA with season (2 levels: open and closed; fixed and orthogonal), protection (2 levels: LPZ and SC; fixed and orthogonal), location (2 levels random and nested within protection), site (2 levels random and nested within time, protection and location) and 30 replicates (10 per year). Data were further examined by running the analysis separately for each year. The factor year was not considered in the analyses in order to provide a denominator for the terms of interest (Underwood, 1997). These analyses allowed us to examine the cumulative effects of protection (all years combined) as well as the inter-annual variability in the effect of LPZs.

The size structure of limpet populations in LPZs and SCAs was compared using the Kolmogorov-Smirnov test. For each year, data were combined among spatial scales (locations and sites) within each level of protection.

The non-standardized estimates of limpet harvesting intensity were analysed using $95 \%$ confidence intervals. For the standardized data, a two-way factorial ANOVA with season (2 levels fixed) and location (2 levels fixed) and 10 replicates was used.

\section{RESULTS}

\section{Limpet population structure}

A total of 2150 Patella candei was counted during the 3 years of the study and had a mean shell length of $12.4 \pm 0.1 \mathrm{~mm}$ (mean $\pm 1 \mathrm{SE}$ ) and $13.0 \pm 0.1 \mathrm{~mm}$ outside and inside LPZs, respectively. When considering cumulative effects of LPZs (all the 3-years combined), although data suggest that, on average, SCAs supported a greater abundance of limpets than did LPZs (Figure 2) the difference was not significant (Table 1). There was, however, a significant 'season $x$

Table 4. Two-way factorial ANOVA comparing the per day mean number of limpet harvesters in two locations (one limpet protected zone and one seasonally closed area) during the open and closed harvesting seasons of 2008. This corresponds to the analysis of the 'standardized' comparison (see Materials and Methods for further details).

\begin{tabular}{llll}
\hline Source & df & MS & F \\
\hline Season & 1 & 25.56 & 3.68 \\
Location & 1 & 75.43 & $10.87^{* *}$ \\
Season $\times$ location & 1 & 25.56 & 3.68 \\
Residual & 36 & 6.96 & \\
Transformation & & ArcSin & \\
Cochran's & & $C=0.49$ & \\
\hline
\end{tabular}


location' interaction (Table 1). Student-Newman-Keuls (SNK) tests revealed that limpet density was significantly greater by the end of the closed fishing season regardless of the level of protection (Figure 2; Table 1). Similar results were also obtained for the limpet biomass (Figure 2; Table 1).

Despite significant variation in space and time, the main factor 'protection' and the interaction 'protection $\times$ season' were never significant in any of the 3 years examined (Tables 2 \& 3) suggesting that there was no inter-annual variation in the effect of protection between LPZs and SCAs. There was, however, a significant effect of season in limpet density in 2006 (Table 2) and interactive effects of season and location (within levels of protection) on density of limpets in 2008 (Table 2) and on biomass of limpets in both 2007 and 2008 (Table 3). SNK analyses revealed that limpet abundance and biomass generally tended to be greater by the end of the closed harvesting season.

Analysis of size structure showed inconsistent results between years (Figure 3). At the end of the closed harvesting season, limpets were significantly larger outside the LPZ in 2007 and 2008 but not in 2006. At the end of the open harvesting season, however, limpets inside the LPZs were larger than in SCAs only in 2007, suggesting that protection in the form of LPZs is generally ineffective.

It should be noted that the density of limpets decreased by the end of the open fishing season in both LPZs and SCAs and that no specimen was larger than the legal minimum size (30 mm shell length). Hence, it would appear that illegal exploitation was occurring inside LPZs.

\section{Limpet harvesting}

Limpet harvesting was observed in both the LPZs and SCAs. The non-standardized data (Figure $4 \mathrm{~A}$ ) showed that, over a period of 3 years, limpets were collected irrespective of location status (LPZ versus SCA) or season (open versus closed harvesting season). Note that sampling effort was substantially different among locations. For instance, Lagoa and Maia were visited over 15 times per year, whilst Fenais and Maia were visited only $2-3$ times per year. This probably explains the greater number of zeros at these locations (Figure $4 \mathrm{~A}$ ).

The standardized analysis (Figure $4 \mathrm{~B}$ ) showed that harvesting frequency was significantly greater in the SCA with a per-day number of harvesters of $0.7 \pm 0.2$ (mean $\pm 1 \mathrm{SE})$ in comparison with the $0.1 \pm 0.1$ in the LPZ (Table 4). The number of harvesters did not show significant variation between seasons although it tended to be greater during the open fishing season in the SCA (closed fishing season: $0.3 \pm 0.2$ harvesters.day ${ }^{-1}$; open fishing season: $1.1 \pm 0.3$ harvesters.day ${ }^{-1}$ ).

\section{DISCUSSIDN}

Two main reasons are usually advocated for use of closed fishing seasons: reduction of effort and avoidance of disturbance during reproduction. The latter argument is of little importance for species such as limpets that do not aggregate to reproduce or whose reproduction is not affected by the act of harvesting (Arendse et al., 2007). Closed fishing seasons can, however, be an effective means of reducing overall fishing effort. In our study, the cumulative effects of LPZs and SCAs on limpet abundance and biomass were similar and there was only a marginal effect of LPZs on mean animal size. This could suggest either that harvesting of limpets during the open fishing season has little effect on limpet population structure, or that LPZs are ineffective. Considering that population structure of limpets (both in LPZs and SCAs) showed clear signs of exploitation (no individuals were larger than the legal catch size and the abundance decreased during the open fishing season), this suggests that inefficiency of LPZs (e.g. due to illegal harvesting) is a more plausible explanation.

Martins et al. (1987) have argued that the opportunistic life-history of $P$. candei renders it relatively insensitive to recruitment exploitation. However, populations of $P$. candei are now extinct in all but one of the 9 islands of the Canaries (Núñez et al., 2003). In the Azores, there was evidence of recruitment failure in the smaller islands (Martins et al., 2008a). In addition, compared to 1988 (Hawkins et al., 1990), the mean abundance of Patella candei decreased from $\sim 61$ to $7.2 \mathrm{~m}^{-2}$ (Caloura, was used for comparison and data were pooled over the 3 years for the present study). Such dramatic decrease in population despite 16 years of ostensible protection suggests that not only is $P$. candei susceptible to recruitment exploitation but that LPZs and SCAs have been largely ineffective as a means of protection.

Generally, only season had a significant effect on limpet abundance, which was greater at the end of the closed fishing season. However, this was evident in both LPZs and SCAs suggesting that this was not the result of fishing closed seasons per se. Although P. candei can spawn throughout the year (Martins et al., 1987), recent work has shown that there is a peak spawning event occurring in late summer (Cúrdia et al., 2005). Hence, the greater abundance of limpets by the end of the closed harvesting season was probably the result of previous recruitment.

The abundance and size of exploited species generally increases after the establishment of marine reserves (Halpern \& Warner, 2002; Halpern, 2003; Micheli et al., 2004; Guidetti \& Sala, 2007; Claudet et al., 2008). What is affecting the lack of recovery of limpet stocks in the Azores? Lack of significant effects of marine reserves have also been reported. For instance, Parnell et al. (2005) showed no clear benefits from protection in a marine reserve in California 30 years after fishing ceased. Likewise, Denny \& Babcock (2004) showed that a seasonal restriction to fishing in New Zealand was ineffective in protecting the locally exploited stocks of snappers. Illegal harvesting can severely influence the success of conservation strategies (Kritzer, 2004; Little et al., 2005; Samoilys et al., 2007; Guidetti et al., 2008), especially in the intertidal where the resources are accessible and have no refuge from harvesters, and a single collection can be extensive and result in longlasting effects. The increasing perception that no-take marine reserves are areas of biomass accumulation where target species occur at larger numbers and attain a larger size may also increase the appeal for poaching (Sethi \& Hilborn, 2008). Keough \& Quinn (2000) found that effective protection of Australian marine reserves required physical barriers and greatly increased enforcement to prevent human harvesting. Guidetti et al. (2008) also showed that the success of marine protected areas along the Italian coast was related to the level of enforcement and that of the 15 marine reserves examined, only 3 had levels of enforcement that were adequate to effectively protect exploited stocks. Illegal harvesting is a worldwide phenomenon and may explain why some marine protected areas, including those examined here, fail to fulfil their role. 
Although variable in space and time, limpet harvesting was recorded regardless of the level of protection (LPZ versus SCA) or fishing season (open versus closed) and this was true for all the four locations examined. Our standardized estimates indicate that LPZs could receive at least 37 harvesters per year. Although this level of exploitation was much lower than that recorded in the SCA, it could still severely impact limpet populations. Inspection of illegal catches showed that large amounts of animals were caught (approximately 2$3 \mathrm{~kg}$ per visit) and that only $3 \%$ of these were larger than the legal catch size (Martins, unpublished data). Clearly, legislation and current levels of enforcement are insufficient to protect these populations and greater levels of enforcement, the establishment of physical barriers and other protective strategies should be considered to protect limpet populations.

Patellid limpets are keystone grazers with an important ecological role (e.g. Hawkins \& Hartnoll, 1983; Coleman et al., 2006) and their over-exploitation will likely be followed by changes in the structure and functioning of intertidal ecosystems. For instance, compared to Flores where limpet abundance is significantly greater, the mid-tidal zone of the rocky intertidal of São Miguel has a far greater cover of turf-forming algae whilst the cover of barnacles has been reduced (Martins et al., 2008a) thus shifting the ecosystem balance between consumers and primary producers. Limpets are also an important component of the diet of a number of marine predators such as birds and crabs. Hence, decreasing abundances of limpets may also affect the structure of intertidal systems at higher trophic levels. For instance, Hockey (1987) suggested that the extinction of the Canarian black oystercatcher was the result of depletion of limpets by human harvesting.

In the absence of adequate enforcement, a complementary approach that has had positive results is co-management (Costello et al., 2008). For instance, in Chile the so-called Management and Exploitation Areas for Benthic Resources (MEABRs), grant territorial user rights to small-scale fishers who share the management of local resources in well-defined coastal areas (Odendaal et al., 1994; Gelcich et al., 2005, 2008) thus promoting the sustainable exploitation of resources. MEABRs arise from an increasing awareness of the need to increase ownership of conservation areas and to involve all interested parties in the development of management schemes (Baxter, 2001; Thompson et al., 2002).

\section{ACKNDWLEDGEMENTS}

This study was conducted in partial fulfilment of a PhD by G.M.M. and funded by Fundação para a Ciência e Tecnologia (SFRH/BD/22009/2005). S.J.H. and S.R.J. were funded by NERC grant-in-aid to the Marine Biological Association and more recently the Oceans 2025 Programme. The present manuscript greatly benefited from comments of two anonymous referees.

\section{REFERENCES}

Abesamis R.A. and Russ G.R. (2005) Density-dependent spillover from a marine reserve: long-term evidence. Ecological Applications 15, 1798 1812 .

Alcala A.C. (1988) Effects of marine reserves on coral fish abundances and yields of Philippine coral reefs. Ambio 17, 194-199.
Arendse C.J., Govender A. and Branch G.M. (2007) Are closed fishing seasons an effective means of increasing reproductive output? A perrecruit simulation using the limpet Cymbula granatina as a case history. Fisheries Research 85, 93-100.

Baxter J.M. (2001) Establishing management schemes on marine special areas of conservation in Scotland. Aquatic Conservation: Marine and Freshwater Ecosystems 11, 261-265.

Bell J.D. (1983) Effects of depth and marine reserve fishing restrictions on the structure of a rocky reef fish assemblage in the north-western Mediterranean Sea. Journal of Applied Ecology 20, 357-369.

Branch G.M. (1975) Notes on the ecology of Patella concolor and Cellana capensis, and the effects of human consumption on limpet populations. Zoologica Africana 10, 263-282.

Branch G.M. and Moreno C.A. (1994) Intertidal and subtidal grazers. In Siegfried W.P. (ed.) Rocky shores: exploitation in Chile and South Africa. Berlin: Springer-Verlag, pp. 75-100.

Branch G.M. and Odendaal F. (2003) The effects of marine protected areas on the population dynamics of a South African limpet, Cymbula oculus, relative to the influence of wave action. Biological Conservation 114, 255-269.

Claudet J., Osenberg C.W., Benedetti-Cecchi L., Domenici P., García-Charton J.-A., Ruzafa A., Badalamenti F., Bayle-Sempere J., Brito A., Bulleri F., Culioli J.-M., Dimech M., Falco J.M., Guala I., Milazzo M., Sánchez-Meca J., Somerfield P.J., Stobart B., Vandeperre F., Valle C. and Planes S. (2008) Marine reserves: size and age do matter. Ecology Letters 11, 481-489.

Coleman R.A., Underwood A.J., Benedetti-Cecchi L., Åberg P., Arenas F., Arrontes J., Castro J., Hartnoll R.G., Jenkins S.R., Paula J., Della Santina P. and Hawkins S.J. (2006) A continental scale evaluation of the role of limpet grazing on rocky shores. Oecologia 147, 556-564.

Costello C., Gaines S.D. and Lynham J. (2008) Can catch shares prevent fisheries collapse? Science 321, 1678-1681.

Cúrdia J, Rodrigues A.S., Martins A.M.F. and Costa M.J. (2005) The reproductive cycle of Patella candei gomesii Drouët, 1858 (Mollusca: Patellogastropoda), an Azorean endemic subspecies. Invertebrate Reproduction and Development 48, 1-3.

Denny C.M. and Babcock R.C. (2004) Do partial marine reserves protect reef fish assemblages? Biological Conservation 116, 119-129.

Fernández-Rueda P. and García-Florez L. (2007) Octupus vulgaris (Mollusca: Cephalopoda) fishery management assessment in Asturias (north-west Spain). Fisheries Research 83, 351-354.

Ferraz R.R., Menezes G.M. and Santos R.S. (2001) Limpet (Patella spp.) (Mollusca: Gastropoda) exploitation in the Azores during the period 1993-1998. Arquipélago-Life and Marine Sciences Supplement 2 (Part B), 59-65.

Gelcich S., Edwards-Jones G. and Kaiser M.J. (2005) Importance of attitudinal differences among artisanal fishers toward co-management and conservation of marine resources. Conservation Biology 19, 865-875.

Gelcich S., Godoy N., Prado L. and Castilla J.C. (2008) Add-on conservation benefits of marine territorial user rights fishery policies in central Chile. Ecological Applications 18, 273-281.

Gell F.R. and Roberts C.M. (2003) Benefits beyond boundaries: the fishery effects of marine reserves. Trends in Ecology and Evolution $18,448-455$.

Govender A., Al-Oufi H., McIlwain J.L. and Claereboudt M.C. (2006) A per-recruit assessment of the kingfish (Scomberomorus commerson) resource of Oman with an evaluation of the effectiveness of some management regulations. Fisheries Research 77, 239-247

Guidetti P., Milazzo M., Bussoti S., Molinaru A., Murenu M., Pais A., Spanó N., Balzano R., Boero F., Carrada G., Cattaneo-Vietti R. 
Cau A., Chemello R., Greco S., Manganaro A., Sciara G.N., Russo G.F. and Tunesi L. (2008) Italian marine reserve effectiveness: does enforcement matter? Biological Conservation 141, 699-709.

Guidetti P. and Sala E. (2007) Community-wide effects of marine reserves in the Mediterranean Sea. Marine Ecology Progress Series 335, 43- 56.

Halpern B.S. (2003) The impact of marine reserves: do reserves work and does reserve size matter? Ecological Applications 13, s117-s137.

Halpern B.S. and Warner R.R. (2002) Marine reserves have rapid and lasting effects. Ecology Letters 5, 361-366.

Hawkins S.J., Burnay L.P., Neto A.I., Cunha R.T. and Martins A.M.F. (1990) A description of the zonation patterns of molluscs and other important biota on the south coast of São Miguel, Azores. Açoreana Supplement, $21-38$.

Hawkins S.J., Côrte-Real H.B.S.M., Pannacciulli F.G., Weber L.C. and Bishop J.D.D. (2000) Thoughts on the ecology and evolution of the intertidal biota of the Azores and other Atlantic islands. Hydrobiologia 440, 3-17.

Hawkins S.J. and Hartnoll R.G. (1983) Grazing of intertidal algae by marine invertebrates. Oceanography and Marine Biology: an Annual Review 21, 195-282.

Hockey P.A.R. (1987) The influence of coastal utilisation by man on the presumed extinction of the Canarian black oystercatcher Haematopus meadewaldoi Bannerman. Biological Conservation 39, 49-62.

Jackson J.B.C., Kirby M.X., Berger W.H., Bjorndal K.A., Botsford L.W., Bourque B.J., Bradbury R.H., Cooke R., Erlandson J., Estes J..A, Hughes T.P., Kidwell S., Lange C.B., Lenihan H.S., Pandolfi J.M., Peterson C.H., Steneck R.S., Tegner M.J. and Warner R.R (2001) Historical overfishing and the recent collapse of coastal ecosystems. Science 293, 629-637.

Kaunda-Arara B. and Rose G.A. (2004) Effects of marine reef National Parks on fishery CPUE in coastal Kenya. Biological Conservation $118,1-13$.

Keough M.J. and Quinn G.P. (2000) Legislative vs. practical protection of an intertidal shoreline in southern Australia. Ecological Applications 10, $871-881$.

Kritzer J.P. (2004) Effects of noncompliance on the success of alternative designs of marine protected-area networks for conservation and fisheries management. Conservation Biology 18, 1021-1031.

Lasiak T. (1993) Temporal and spatial variations in exploited and non-exploited populations of the intertidal limpet Cellana capensis. Journal of Molluscan Studies 59, 295-307.

Little L.R., Smith A.D.M., McDonald A.D., Punt A.E., Mapstone B.D., Pantus F. and Davies C.R. (2005) Effects of size and fragmentation of marine reserves and fisher infringement on the catch and biomass of coral trout, Plectropomus leopardus, on the Great Barrier Reef, Australia. Fisheries Management and Ecology 12, 177-188.

Lubchenco J., Palumbi S.R., Gaines S.D. and Andelman S. (2003) Plugging a hole in the ocean: the emerging science of marine reserves. Ecological Applications 13, s3-s7.

Martins G.M. (2009) Community structure and dynamics of the Azorean rocky intertidal: exploitation of keystone species. $\mathrm{PhD}$ thesis. University of Plymouth, UK.

Martins G.M., Jenkins S.R., Hawkins S.J., Neto A.I. and Thompson R.C. (2008a) Exploitation of rocky intertidal grazers: population status and potential impacts on community structure and functioning. Aquatic Biology 3, 1-10.

Martins G.M., Thompson R.C., Hawkins S.J., Neto A.I. and Jenkins S.R. (2008b) Rocky intertidal community structure in oceanic islands: scales of spatial variability. Marine Ecology Progress Series $356,15-24$
Martins H.R., Santos R.S. and Hawkins S.J. (1987) Estudos sobre as lapas dos Açores: exploração e avaliação. Relatório da XVII Semana das Pescas dos Açores. Universidade dos Açores, Horta.

McClanahan T.R. and Muthiga N.A. (1988) Changes in Kenyan coral reef community structure and function due to exploitation. Hydrobiologia 166, 269-276.

Micheli F., Halpern B., Botsford L.W. and Warner R.R. (2004) Trajectories and correlates of community change in no-take marine reserves. Ecological Applications 14, 1709-1723.

Morton B., Britton J.C. and Martins A.M.F. (1998) Coastal ecology of the Azores. Ponta Delgada: Sociedade Afonso Chaves.

Myers R.A. and Worm B. (2003) Rapid worldwide depletion of predatory fish communities. Nature 423, 280-283.

Núñez J., Brito M.C., Riera R., Docoito J.R. and Monterroso O. (2003) Present distribution of the populations of Patella candei D'Orbigny, 1840 (Mollusca, Gastropoda) in the Canary Islands. A species in danger of extinction. Boletin del Intituto Español de Oceanografia 19, 371-377.

Odendaal F.J., Bergh M.O. and Branch G.M. (1994) Socio-economic options for the management of exploitation of intertidal and subtidal resources. In Siegfried W.R. (ed.) Rocky shores: exploitation in Chile and South Africa. Berlin: Springer-Verlag, pp. 155-168

Parnell P.E., Lennert-Cody C.E., Stanley L.D. and Dayton P.K. (2005) Effectiveness of a small marine reserve in southern California. Marine Ecology Progress Series 296, 39-52.

Roberts C.M. and Polunin N.V.C. (1991) Are marine reserves effective in management of reef fisheries? Reviews in Fish Biology and Fisheries 1, $65-91$.

Samoilys M.A., Martin-Smith K.M., Giles B.G., Cabrera B., Anticamara J.A., Bruno E.O. and Vincent A.C.J. (2007) Effectiveness of five small Philippines' coral reef reserves for fish populations depends on sitespecific factors, particularly enforcement history. Biological Conservation 136, 584-601.

Santos R.S., Martins H.R. and Hawkins S.J. (1990) Relatório de estudos sobre o estado das populações de lapas do Arquipélago dos Açores e da ilha da Madeira. Relatório da X Semana das Pescas dos Açores. Universidade dos Açores, Horta.

Sethi S.A. and Hilborn R. (2008) Interactions between poaching and management policy affect marine reserves as conservation tools. Biological Conservation 141, 506-516.

Shears N.T. and Babcock R.C. (2003) Continuing trophic cascade effects after 25 years of no-take marine reserve protection. Marine Ecology Progress Series 246, 1-16.

Thompson R.C., Crowe T.P. and Hawkins S.J. (2002) Rocky intertidal communities: past environmental changes, present status and predictions for the next 25 years. Environmental Conservation 29, 168-191.

Underwood A.J. (1997) Experiments in ecology: their logical design and interpretation using analysis of variance. Cambridge: Cambridge University Press.

and

Ye Y. (1998) Assessing effects of closed seasons in tropical and subtropical panaeid shrimp fisheries using a length-based yield-per-recruit model. ICES Journal of Marine Science 55, 1112-1124.

Correspondence should be addressed to:

G.M. Martins

Secção Biologia Marinha

Departamento Biologia

Universidade dos Açores, 9501-801 Ponta Delgada

Açores, Portugal

email: gmartins@uac.pt 